\title{
Interobserver Error in Scoring Nonmetric Cranial Traits
}

\author{
Hajime ISHIDA and Yukio DoDO \\ Department of Anatomy, Sapporo Medical College
}

\begin{abstract}
Interobserver errors in scoring presence or absence were investigated for 31 nonmetric cranial traits based on a sample of 203 almost complete Polynesian skulls using the correlation coefficients of attributes. The $\phi$ coefficients for all 31 traits were statistically significant at the 0.01 level. When the $\phi$ value of +0.7 was regarded as the critical point for assessing interobserver replicability, 20 traits were selected. Since the MMD on these 20 traits did not reach the significant level of 0.05 , these traits were considered to be reliable for comparisons between different observers. Because interobserver error was larger than intraobserver error and some anthropologically important traits did not clear the threshold for assessing consistency, it is recommended that physical anthropologists should investigate nonmetric cranial traits by themselves.
\end{abstract}

Keywords Interobserver error, Nonmetric trait, Skull, Polynesian

\section{Introduction}

Human morphological variations have been studied in terms of craniometry, nonmetric cranial traits, dental morphology and anthropometry for a long time. When someone's anthropological data are compared with the data of other researchers, the inconsistency of measurements or trait scorings becomes a serious problem for making comparisons. Many anthropologists have examined intra- and interobserver errors in craniometry (PAGE, 1976; UTERMOHLE and ZEGURA, 1982; SAKURA and MIZOGUCHI, 1983; KOUCHI and KOIZUMI, 1985), anthropometry (JAMISON and ZEGURA, 1974; KOUCHI and HANIHARA, 1981; JOHNSTONE and MACK, 1985; SHIOZAWA, 1985; BENNETT and OSBORNE, 1986; JAMISON et al., 1989) and dental morphology (MIZOGUCHI, 1977, 1978; NICHOL and TURNER, 1986). Although it is commonly believed that nonmetric traits are subject to greater intra- and interobserver error than metric traits, only a few analyses on observer error have been made for nonmetric cranial traits. MOLTO (1979) investigated intraobserver error in scoring nonmetric cranial traits and found high consistency for most traits.

The aim of this study was to examine 31 nonmetric cranial variant traits for assessing the replicability between two observers and to determine those traits which are the most consistent for different observers.

\section{Materials and Methods}

A sample of 203 male and female Polynesian skulls from the Mokapu site, Oahu island,

Article No. 9007 Received June 7, 1990 
Hawaii, was examined for 31 nonmetric traits. This skeletal collection was studied by SNOW (1974) and is now housed at the B. P. BISHOP Museum, Honolulu, Hawaii (PIETRUSEWSKY, 1971). Only almost complete skulls with mandibles were used for this analysis, though this Mokapu series consists of more than 1,500 skeletons. The nonmetric data of modern Japanese was used for calculating MMDs from the Mokapu series (DODO and ISHIDA, 1987).

The second author (Y.D.) has defined the criteria of presence or absence for each variant (DoDO, 1972, 1974, 1986a). The Mokapu series was individually examined for nonmetric cranial traits on both right and left sides by the first observer (H.I.) in 1987, and by the second observer (Y.D.) in 1988. The nonmetric data of the Mokapu series presented by H.I. is named "Mokapu-1" and the data given by Y.D. is named "Mokapu-2" for convenience of explanation. The statistical tests selected to examine interobserver concordance are the four-fold point correlation coefficient ( $\phi$ coefficient) and YULE's coefficient of association (Q), as described below (YASUDA and UMINO, 1977):

$\phi$ coefficient: $r=\frac{p_{11} p_{22}-p_{12} p_{21}}{\sqrt{\left(p_{1 .}\right)\left(p_{.1}\right)\left(p_{2 .}\right)\left(p_{.2}\right)}}$

YULE's coefficient of association:

$$
Q=\frac{p_{11} p_{22}-p_{12} p_{21}}{p_{11} p_{22}+p_{12} p_{21}}
$$

where $p_{11}=$ common presence recorded by both observers

$p_{22}=$ common absence recorded by both observers

$p_{12}=$ scored present by one observer (H.I.) and absent by the second observer (Y.D.)

$p_{21}=$ scored absent by one observer (H.I.) and present by the second observer (Y.D.)

$$
\begin{array}{ll}
p_{1 .}= & \text { sum of } p_{11}+p_{12} \\
p_{2 .}= & \text { sum of } p_{21}+p_{22} \\
p_{.1}= & \text { sum of } p_{11}+p_{21} \\
p_{.2}= & \text { sum of } p_{12}+p_{22}
\end{array}
$$

The null hypothesis that $\phi$ coefficient is equal to zero was examined by using the $\chi^{2}$ test (IWAHARA, 1968). The biological distance between the two sets of observations was estimated by the mean measure of divergence (MMD). The variance of MMD defined by SJøVOLD (1973) was used for the significance tests of MMD.

\section{Results}

The data of interobserver inconsistencies and the two coefficients are given in Table 1 . The $\dot{\phi}$ coefficients for all traits reach statistically significant levels, because the null hypotheses are rejected at the 0.01 level by $\chi^{2}$ tests. All the YULE's coefficients of association except that of the palatine torus have quite high values. We classified the 31 nonmetric traits into three groups based on the values of the $\phi$ coefficients.

The $\phi$ coefficients of the first group range from 0.85 , which is almost equal to the 0.7 of $\phi$ squared, to 1. MOLTO (1979) determined this $\phi$ squared value as the threshold for observational repeatability. The first group consists of the following 9 traits: metopism, supraorbital nerve groove, supraorbital foramen, interparietals, paracondylar process, hypoglossal canal bridging, pterygo-spinous foramen, medial palatine canal, and mylohyoid bridging. The mean of discordances of these 9 traits is only $0.7 \%$ and the highest discordance is $3.23 \%$ for the trait of supraorbital foramen.

The $\phi$ coefficients of the second group range between 0.7 and 0.85 . This group consists of the following 11 nonmetric traits: foramen meningoorbitale, accessory infraorbital foramen, ossicle 
Table 1. The $\phi$ and $Q$ coefficients for testing interobserver errors of 31 minor cranial variants

\begin{tabular}{|c|c|c|c|c|c|c|c|}
\hline & $p_{11}$ & $p_{22}$ & $p_{12}$ & $p_{21}$ & $\phi$ & Q & Discordances* \\
\hline 1. Metopism** & 0 & 203 & 0 & 0 & 1.0000 & 1.0000 & 0 \\
\hline 2. Supraorbital nerve groove** & 64 & 327 & 3 & 5 & 0.9292 & 0.9986 & 0.0200 \\
\hline 3. Supraorbital foramen** & 180 & 210 & 1 & 12 & 0.9366 & 0.9994 & 0.0323 \\
\hline 4. Foramen meningo-orbitale & 43 & 325 & 4 & 27 & 0.7104 & 0.9847 & 0.0777 \\
\hline 5. Accessory infraorbital foramen & 28 & 353 & 15 & 4 & 0.7307 & 0.9879 & 0.0475 \\
\hline 6. Ossicle at the lambda** & 5 & 184 & 3 & 1 & 0.7116 & 0.9935 & 0.0207 \\
\hline 7. Interparietals & 4 & 198 & 0 & 0 & 1.0000 & 1.0000 & 0 \\
\hline 8. Biasterionic suture** & 21 & 356 & 9 & 18 & 0.5787 & 0.9576 & 0.0668 \\
\hline 9. Asterionic bone** & 24 & 354 & 18 & 7 & 0.6330 & 0.9708 & 0.0620 \\
\hline 10. Occipito-mastoid wormians** & 49 & 310 & 20 & 20 & 0.6495 & 0.9487 & 0.1003 \\
\hline 11. Parietal notch bone** & 19 & 373 & 8 & 2 & 0.7856 & 0.9955 & 0.0249 \\
\hline 12. Condylar canal** & 210 & 129 & 12 & 27 & 0.7868 & 0.9764 & 0.1032 \\
\hline 13. Third occipital condyle & 1 & 193 & 3 & 0 & 0.4962 & 1.0000 & 0.0152 \\
\hline 14. Precondylar tubercle** & 47 & 315 & 1 & 31 & 0.7302 & 0.9958 & 0.0812 \\
\hline 15. Paracondylar process ${ }^{* *}$ & 4 & 378 & 1 & 0 & 0.8932 & 1.0000 & 0.0026 \\
\hline 16. Hypoglossal canal bridging** & 26 & 374 & 0 & 2 & 0.9611 & 1.0000 & 0.0050 \\
\hline 17. Foramen of HUSCHKE** & 24 & 336 & 41 & 3 & 0.5302 & 0.9699 & 0.1089 \\
\hline 18. Foramen ovale incomplete** & 6 & 392 & 1 & 2 & 0.7980 & 0.9983 & 0.0075 \\
\hline 19. Foramen of VESALIUS** & 44 & 202 & 3 & 19 & 0.7625 & 0.9873 & 0.0821 \\
\hline 20. Pterygo-spinous foramen** & 12 & 391 & 0 & 1 & 0.9595 & 1.0000 & 0.0025 \\
\hline 21. Medial palatine canal** & 12 & 386 & 1 & 0 & 0.9595 & 1.0000 & 0.0025 \\
\hline 22. Aural exostosis & 56 & 328 & 4 & 16 & 0.8241 & 0.9931 & 0.0495 \\
\hline 23. Transverse zygomatic suture** & 1 & 341 & 2 & 1 & 0.4041 & 0.9883 & 0.0087 \\
\hline 24. Clinoid bridging** & 12 & 349 & 4 & 1 & 0.8254 & 0.9981 & 0.0137 \\
\hline 25. Accessory mental foramen & 18 & 323 & 14 & 5 & 0.6368 & 0.9762 & 0.0528 \\
\hline 26. Mylohyoid bridging** & 22 & 345 & 0 & 0 & 1.0000 & 1.0000 & 0 \\
\hline 27. Mandibular torus** & 5 & 336 & 1 & 12 & 0.4823 & 0.9858 & 0.0367 \\
\hline 28. Jugular foramen bridging** & 11 & 377 & 5 & 4 & 0.6983 & 0.9904 & 0.0227 \\
\hline 29. Intermediate condylar canal & 76 & 292 & 11 & 16 & 0.8055 & 0.9843 & 0.0684 \\
\hline 30. Sagittal groove left ${ }^{* *}$ & 20 & 163 & 12 & 7 & 0.6264 & 0.9498 & 0.0941 \\
\hline 31. Palatine torus & 42 & 89 & 7 & 58 & 0.4007 & 0.8040 & 0.3316 \\
\hline
\end{tabular}

*: $\left(p_{12}+p_{21}\right) /\left(p_{11}+p_{22}+p_{12}+p_{21}\right)$

**: These 23 traits are usually used for calculating MMDs (DODO and ISHIDA, 1987)

at the lambda, parietal notch bone, condylar canal, precondylar tubercle, foramen ovale incomplete, foramen of VESALIUS, aural exostosis, clinoid bridging, and intermediate condylar canal. The mean of discordances is $5.24 \%$, but the discordance of the condylar canal trait is over $10 \%$.

The traits of the third group have lower values of the $\phi$ coefficient, being under 0.7 . The third group consists of the following 11 traits: biasterionic suture trace, asterionic bone, occipito-mastoid wormians, third occipital condyle, foramen of HUSCHKE, transverse zygomatic suture, accessory mental foramen, mandibular torus, jugular foramen bridging, sagittal groove left turn, and palatine torus. The mean of discordances is $8.18 \%$ and the discordance of the palatine torus shows the highest value $(33.16 \%)$. Because of quite a low incidence of the transverse zygomatic suture, the $\phi$ coefficient of this variant is under 0.5 , but the discordance is one of the lowest values. 
Table 2. The MMDs and their standard deviations between the Mokapu-1 and Mokapu-2

\begin{tabular}{rlcc}
\hline & Traits used & MMD & SD \\
\hline 9 & variants $(\phi:$ over 0.85$)$ & -0.009 & 0.0048 \\
20 & variants $(\phi:$ over 0.7$)$ & 0.0032 & 0.0033 \\
31 & variants & $0.0315^{*}$ & 0.0027 \\
\hline
\end{tabular}

*: The MMD is significant at the 0.05 level.

MMDs between Mokapu-1 and Mokapu-2 were computed based on the skull incidences of the three sets of nonmetric traits. The MMDs and their standard deviations are given in Table 2. The MMD based on the 9 nonmetric traits of the first group is under zero, and the MMD and its standard deviation based on the 20 traits of the first and second groups are 0.0032 and 0.0033 , respectively. These two MMDs do not reach the significant level of 0.05 . The MMD and its standard deviation based on all 31 nonmetric cranial traits are 0.0315 and 0.0027 , respectively.
This MMD is significant at the 0.05 level.

The MMDs from the modern Japanese are given in Fig. 1 for comparison. Twenty-three cranial traits on which the MMDs were previously calculated were employed in this case (DODO and ISHIDA, 1987), as shown in Table 1. The schema shows that the MMD based on eight nonmetric traits ( $\phi \geq 0.85$ ) between Mokapu-1 and the Japanese is almost the same as that between Mokapu-2 and the Japanese, although about half of the information was lost. The MMD between Mokapu-1 and Mokapu-2 on 15 traits ( $\phi \geq 0.7)$ is 0.003 and not significant, whereas on 23 traits it is fairy large (0.028) and significant at the 0.05 level.

\section{Discussion}

As Molto (1979) mentioned, most researchers working with discontinuous traits have not checked their data for intraobserver error nor their comparative data for interobserver error.
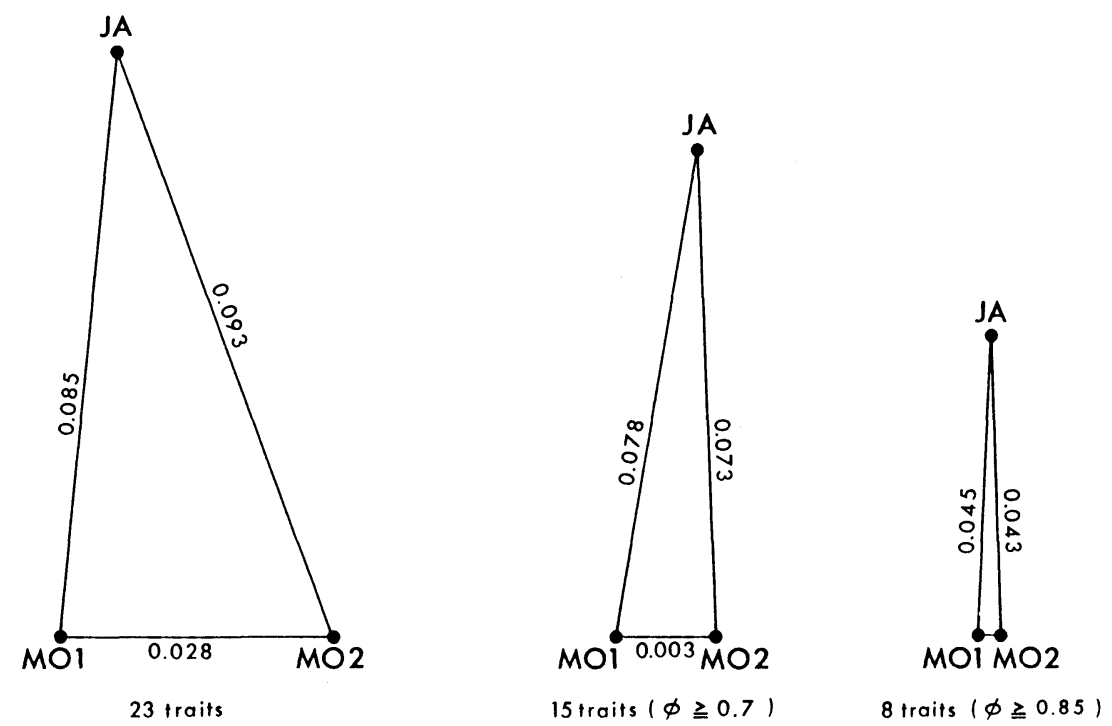

Fig. 1. Schematic representations of the MMDs between modern Japanese, Mokapu-1 and Mokapu-2 based on three sets of nonmetric cranial traits. The MMD between Mokapu-1 and Mokapu-2 on 23 traits is significant at the 0.05 level, whereas neither the MMDs on 15 traits $(\phi \geq 0.7)$ nor 8 traits $(\phi \geq 0.85)$ reach the significant level of 0.05 . JA: Japanese, MO1: Mokapu-1, MO2: Mokapu-2 
For example, physical anthropologists in Japan have employed other observer's data for comparison, considering the other's criteria of presence or absence to be the same as those they have defined for themselves (YAMAGUCHI, 1985; DODO, 1986b; MOURI, 1986).

The traits which are too ambiguous to permit meaningful criteria have a bias toward low scoring consistencies between different observers. This corresponds to measurement errors in craniometry due to the difficulty of the landmark definition (SAKURA and MIZOGUCHI, 1983). MOLTO (1979) has already mentioned that most observational errors in discontinuous traits are random rather than systematic because morphological ambiguity and low precision are highly correlated. To cite an example, tori and some accessory foramina have large interobserver differences, whereas the bridging traits are scored with high precision. It can be said that the influence of observational errors on the results of population studies decreases if the traits of less replicability are not used. On the other hand, evaluating the taxonomic validity of discontinuous nonmetric traits would also be necessary, as OSSENBERG (1976) has recommended. In addition, the use of only complete trait formation might be better for precise scoring (SAUNDERS, 1978).

Observer errors in dental morphological traits are generally higher than those in nonmetric cranial traits. MIZOGUCHI (1978) reported that the intraobserver discordances for dental characters averaged $10.9 \%$. The critical levels for assessing trait reliability in dental morphology are somewhat low and the values of $\phi$ coefficients are fairly low for several dental traits, because it is quite difficult to score graded points exactly, particularly for different observers (NICHOL and TURNER, 1986). In contrast with the analyses of dental characteristics, the threshold in nonmetric cranial traits proposed by MOLTO (1979) is very high: the value of $\phi^{2}$ is 0.7 , almost corresponding to a scoring consistency of $95 \%$. In this study 9 traits cleared this value. If MMDs were based only on these traits, some important information for racial diagnosis would have been lost. We, therefore, determined the $\phi$ value of 0.7 , almost equal to the $\phi^{2}$ of 0.5 , as a critical level. As described before, 20 traits exceeded this critical level. The traits with over 5\% discordance are no more than five of the 20 traits and only one trait is over $10 \%$ for scoring inconsistency. Moreover, the MMD between the two series of observations based on the 20 nonmetric traits is small and insignificant.

The transverse zygomatic suture trace is one of the important traits for discriminating between populations and many researchers have utilized it for nonmetric study (OSSENBERG, 1969; DODO, 1974; YAMAGUCHI, 1985; KOZINTSEV, 1988). Unfortunately, however, its $\phi$ coefficient was 0.404 and thus it was not used for calculating the MMDs in this analysis. The reason for the low coefficient must be that the Mokapu series has an extremely low incidence of transverse zygomatic suture. Therefore it is necessary to reexamine the interobserver concordance of this trait using a population sample whose incidence of the transverse zygomatic suture is relatively high.

It appears from the present and MOLTO's (1979) results that in nonmetric cranial traits the interobserver error is larger than the intraobserver error. Only about half of the nonmetric traits generally listed can be used for distance analysis when the data are compared with those of different observers. In addition, there is a problem that some traits of anthropological importance do not clear the threshold of assessing consistency. Therefore, physical anthropologists working with nonmetric traits had better try to investigate each cranial series by themselves instead of using other observer's data. 


\section{Acknowledgement}

We are especially grateful to Dr. Y. H. SINOTO of the Department of Anthropology, the B. P. BISHOP Museum, for his permission to investigate the cranial materials, and also to $\mathrm{Mr}$. M. UMEDA and Miss H. KAWAGUCHI for their technical assistances. This study was supported in part by Grant-in-aid for International Scientific Research and Scientific Research on Priority Areas from the Ministry of Education, Science and Culture, Japan in 1987-1990.

\section{抄 録}

頭蓋形態小変異における観察者間誤差

\section{石田 肇・百々幸雄}

従来から観察者間誤差が大きいとされる頭蓋形態 小変異について, ポリネシアのモカプ遺跡出土のほ ぼ完全な頭蓋 203 個体を用いて二人が時期をずらし 独沙して 31 項目の調查を抢こない，属性相関係数を 基に観察者間誤差を検討した，骨橋を作る項目は観 察者間の一致度がきわめて高いが，基準自体があい まいであるような骨隆起や副孔などは誤差が大き かった。 ファイ係数はどの項目についても $1 \%$ で有 意であったが, MoLTo (1979) の示した基準 $(\phi \geq$ 0.85)では 9 項目のみが，また閾値を少し下げて $\phi \geq$ 0.7 とすると 20 項目が選択された。 その不一致率は 4 分の 3 が $5 \%$ 内に収まった。この 20 項目を基に二人 の観察者間の Mean Measure of Divergence (MMD) を算出したが, 有意差は認められず，これらの項目に ついてのデー夕は比較可能と推定された。しかし， MoLTo (1979) の調査した観察者内誤差に比較し観察 者間誤差は大きく，しかも人類学的に重要な項目が いくつか除外されてしまったので，形態小変異を扱 う研究者は自ら資料収集に心掛ける必要があると思 われる。

\section{References}

BENETT, K.A. and R.H. OSBORNE, 1986: Interobserver measurement reliability in anthropometry. Hum. Biol., 58: 751-759.

DoDO, Y., 1972: Aural exostoses in the human skeletal remains excavated in Hokkaido. J. Anthrop. Soc. Nippon, 80: 11-22. (In Japanese with English summary)

DODO, Y., 1974: Non-metrical cranial traits in the Hokkaido Ainu and the Northern Japanese of recent times. J. Anthrop. Soc. Nippon, 82: 31-51.

DoDO, Y., 1986a: A population study of the jugular foramen bridging of the human cranium. Am. J. Phys. Anthropol., 69: 15-19.

DODO, Y., 1986b: Metrical and non-metrical analyses of Jomon crania from Eastern Japan. In: AKAZAWA, T. and C.M. AIKENS (eds.) Prehistoric Hunter-Gatherers in Japan: New Research Method. Univ. Mus., Univ. Tokyo, Bull., 27: 137-161.

DODO, Y., and H. ISHIDA, 1987: Incidences of nonmetric cranial variants in several population samples from East Asia and North America. J. Anthrop. Soc. Nippon, 95: 161-177.

IWAHARA, S., 1968: Nonparametric Method. Nihonbunkakagakusha, Tokyo, pp. 148-151. (In Japanese) [岩原信九郎，1968：ノンパラメトリック法. 日本 文化科学社, 東京, pp. 148-151.]

JAMISON, P.L. and S.L. ZEGURA, 1974: A univariate and multivariate examination of measurement error in anthropometry. Am. J. Phys. Anthropol., 40: 197-204.

JAMISON, P.L., R.J. MEIER and D. THOMPSONJACOB, 1989: Meaning of biodistance statistics: A test case using adult monozygotic twins. Am. J. Phys. Anthropol., 80: 485-492.

JOHNSTON, F.E. and R.W. MACK, 1985: Interobserver reliability of skinfold measurements in infants and young children. Am. J. Phys. Anthropol., 67: 285-289.

KOUCHI, M. and K. HANIHARA, 1981: An analysis of errors in somatometric research. J. Anthrop. Soc. Nippon, 89: 493-504.

KOUCHI, M. and K. KOIZUMI, 1985: An analysis of errors in craniometry. J. Anthrop. Soc. Nippon, 93: 409-424.

KOZINTSEV, A.G. 1988: Ethnic Cranioscopy. Nauka, Leningrad, pp.1-166. (In Russian with English summary)

MIZOGUCHI, Y., 1977: Genetic variability in tooth crown characters: Analysis by the tetrachoric correlation method. Bull. Natn. Sci. Mus., Ser. D, 3: 37-62.

MIZOGUCHI, Y., 1978: Tooth crown characters on the lingual surfaces of the maxillary anterior teeth: Analysis of the correlations by the method of path coefficients. Bull. Natn. Sci. Mus., Ser. D, 4: 25-57.

MOLTO, J.E. 1979: The assessment and meaning of intraobserver error in population studies based on discontinuous cranial traits. Am. J. Phys. Anthropol., 51: 333-344. 
MOURI, T., 1986: Geographical and temporal variations of Japanese populations as viewed from nonmetric traits of the skull. Doctoral dissertation, Kyoto University. (In Japanese)

[毛利俊雄, 1986：頭蓋骨の非計測形質からみた日 本列島諸集団の地理的および時代的変異. 京都大 学理学部博士論文]

NICHOL, C.R. and C.G. TURNER II, 1986: Intra- and interobserver concordance in classifying dental morphology. Am. J. Phys. Anthropol., 69: 299-315.

OSSENBERG, N.S. 1969: Discontinuous morphological variation in the human cranium. $\mathrm{Ph}$. $\mathrm{D}$. thesis of University of Toronto, Toronto, pp.1-257.

OSSENBERG, N.S. 1976: Within and between race distances in population studies based on discrete traits of the human skull. Am. J. Phys. Anthropol., 45: 701-715.

PAGE, J.W. 1976: A note on interobserver error in multivariate analyses of populations. Am. J. Phys. Anthropol., 44: 521-526.

PIETRUSEWSKY, M., 1971: Human Skeletal Collections in the BISHOP Museum. Department of Anthropology, Bernice P. BISHOP Museum, Honolulu, pp.1-35.

SAKURA, H. and Y. MIZOGUCHI, 1983: Measurement errors in craniometry. J. Anthrop. Soc. Nippon, 91: 69-78. (In Japanese with English summary)
SAUNDERS, S.R., 1978: The development and distribution of discontinuous morphological variation of the human infracranial skeleton. Natn. Mus. Man, Mercury series, Archaeological Survey of Canada, 81: 1-549.

SHIOZAWA, Y., 1985: Analysis of the errors in somatological measurements in man. J. Anthrop. Soc. Nippon, 93: 399-408. (In Japanese with English summary)

SJøVOLD, T., 1973: The occurrence of minor nonmetrical variants in the skeleton and their quantitative treatment for population comparisons. Homo, 24: 204-233.

SNOW, C.E., 1974: Early Hawaiians: An Initial Study of Skeletal Remains from Mokapu, Oahu. The University Press of Kentucky, Lexington.

UTERMOHLE, C.J. and S.L. ZEGURA, 1982: Intra- and interobserver error in craniometry: A cautionary tale. Am. J. Phys. Anthropol., 57: 303-310.

YAMAGUCHI, B., 1985: The incidence of minor nonmetric cranial variants in the protohistoric human remains from Eastern Japan. Bull. Natn. Sci. Mus., Tokyo, Ser. D, 11: 13-24.

YASUDA, S. and M. UMINO, 1977: Social Statistics. Maruzen, Tokyo, pp.16-56. (In Japanese)

[安田三郎・海野道郎, 1977：社会統計学. 丸善, 東 京, pp. 16-56.]

\section{石田肇札幌医科大学解剖学第 2 講座 干060 札幌市中央区南 1 条西 17 丁目 \\ Hajime IsHIDA Department of Anatomy, Sapporo Medical College \\ South 1, West 17, Chuo-ku, Sapporo 060, Japan}

